\title{
Nurses' performance in palliative care: spiritual care in the light of Theory of Human Caring
}

\author{
Atuação de enfermeiros em cuidados paliativos: cuidado espiritual à luz da Teoria do Cuidado Humano \\ El desempeño de las enfermeras en cuidados paliativos: el cuidado espiritual a la luz de la Teoría del Cuidado Humano
}

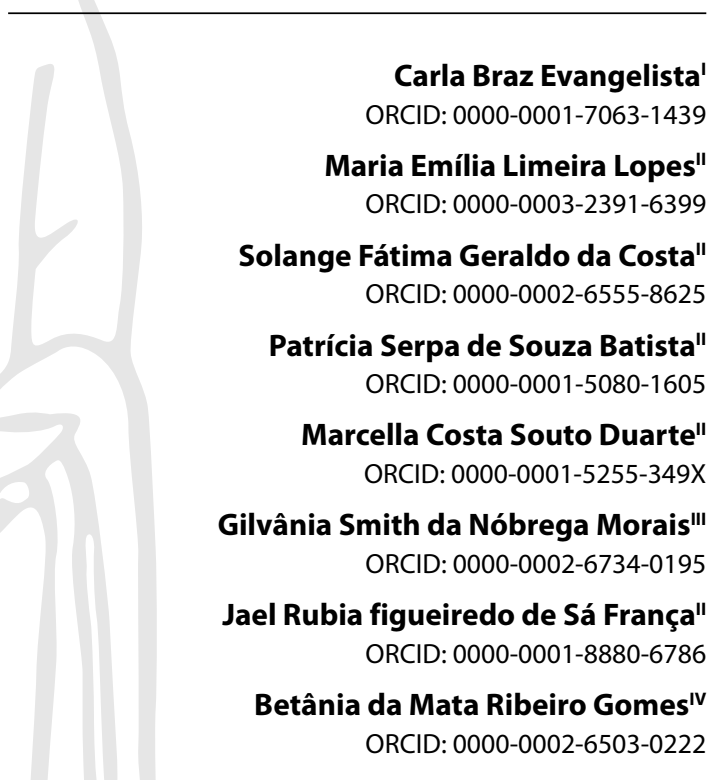

'Centro Universitário de João Pessoa. João Pessoa,

Paraíba, Brazil.

"Universidade Federal da Paraíba. João Pessoa, Paraíba, Brazil.

"'Universidade Federal de Campina Grande. Campina Grande,

Paraíba, Brazil.

"Universidade de Pernambuco. Recife, Pernambuco, Brazil.

How to cite this article:

Evangelista CB, Lopes MEL, Costa SFG, Batista PSS, Duarte MCS, Morais GSN, et al. Nurses' performance in palliative care: spiritual care in the light of Theory of Human Caring. Rev Bras Enferm. 2022;75(1):e20210029. https://doi.org/10.1590/0034-7167-2021-0029

\author{
Corresponding author: \\ Carla Braz Evangelista \\ E-mail: carlabrazevangelista@gmail.com
}

\section{ABSTRACT}

Objectives: to analyze nurses' role in assisting patients in palliative care, with emphasis on the spiritual dimension, in the light of Theory of Human Caring. Methods: this is an exploratory, qualitative study, carried out in a hospital in João Pessoa, Paraíba, between August and December 2019, with 10 nurses. For data collection, semi-structured interviews were used. For analysis, we opted for content analysis. Results: the spiritual dimension of care is contemplated by several religious and spiritual practices. These are respected and encouraged by nurses, although there is difficulty in providing care for the spiritual dimension. Final Considerations: nurses have attitudes consistent with Jean Watson's Theory and apply the Caritas Process elements during assistance to patients'spiritual dimension in palliative care. Descriptors: Nursing; Patients; Palliative Care; Spirituality; Nursing Theory.

\section{RESUMO}

Objetivos: analisar a atuação de enfermeiros na assistência a pacientes em cuidados paliativos, com destaque para a dimensão espiritual, à luz da Teoria do Cuidado Humano. Métodos: estudo exploratório, qualitativo, realizado em um hospital localizado em João Pessoa, Paraíba, entre agosto e dezembro de 2019, com 10 enfermeiros. Para coleta de dados, utilizou-se a entrevista semiestruturada. Para análise, optou-se pela técnica de análise de conteúdo. Resultados: a dimensão espiritual do cuidado é contemplada por diversas práticas religiosas e espirituais. Essas são respeitadas e incentivadas pelos enfermeiros, embora exista dificuldade para realizar o atendimento da dimensão espiritual. Considerações Finais: os enfermeiros possuem atitudes congruentes com a Teoria de Jean Watson e aplicam os elementos do Processo Caritas durante a assistência à dimensão espiritual do paciente em cuidados paliativos.

Descritores: Enfermagem; Pacientes; Cuidados Paliativos; Espiritualidade; Teoria de Enfermagem.

\section{RESUMEN}

Objetivos: analizar el papel del enfermero en la asistencia a los pacientes en cuidados paliativos, con énfasis en la dimensión espiritual, a la luz de la Teoría del Cuidado Humano. Métodos: estudio exploratorio, cualitativo, realizado en un hospital ubicado en João Pessoa, Paraíba, entre agosto y diciembre de 2019, con 10 enfermeras. Para la recolección de datos se utilizaron entrevistas semiestructuradas. Para el análisis, optamos por la técnica de análisis de contenido. Resultados: la dimensión espiritual del cuidado es contemplada por diversas prácticas religiosas y espirituales. Estos son respetados y alentados por las enfermeras, aunque existe dificultad para atender la dimensión espiritual. Consideraciones Finales: las enfermeras tienen actitudes congruentes con la Teoría de Jean Watson y aplican los elementos del Proceso Caritas durante la asistencia a la dimensión espiritual del paciente en cuidados paliativos.

Descriptores: Enfermería; Pacientes; Cuidados Paliativos; Espiritualidad; Teoría de Enfermería.

EDITOR IN CHIEF: Antonio José de Almeida Filho ASSOCIATE EDITOR: Alexandre Balsanelli 


\section{INTRODUCTION}

Chronic diseases are increasing worldwide as well as the life expectancy of individuals affected by them ${ }^{(1-2)}$. Thus, it becomes necessary to establish a care model that contemplates the entire process of patients' illness, death and dying so that it is possible to promote an improvement in the quality of life during illness and finitude, as proposed by palliative care $^{(2)}$.

Palliative care refers to holistic care directed at individuals with potentially fatal diseases, including those at the end of their lives. This care aims to improve the quality of life of patients, with life threatening diseases, and their families/caregivers ${ }^{(3-5)}$. Palliative care must be offered by a multidisciplinary team so that there is excellent care, highlighting nurses' role ${ }^{(6)}$, who must pay attention to patients' real needs, be they physical, psychological, social and spiritual, although it is not always easy to attend to all of them, in their completeness ${ }^{(2)}$.

Regarding the spiritual dimension, nurses' recognition of the importance of attending this dimension stands out. They understand spirituality as something that strengthens, promotes comfort and faith, helping patients to cope with the problem and enabling them to improve their health, even in the face of a life-threatening illness. However, there is still a lack of preparation of these professionals in addressing issues of a spiritual nature ${ }^{(7)}$, although there are nursing theories that contribute greatly to support nurses' practice and that address spiritual issues.

Among the nursing theories that address the spiritual dimension in patient care, the Theory of Human Caring stands out. This theory emphasizes care as opposed to healing, values the mysteries of life, recognizing the spiritual dimension and the inner power in the care process, in which nurses are co-participants ${ }^{(8)}$.

That said, this study is justified by the need for nurses to contemplate the spiritual dimension in assisting patients who are affected by a life-threatening disease, aiming at the relief of their spiritual suffering ${ }^{(7,9)}$, and the possibility for nurses to base their care practice with a theory like that of Jean Watson, which can assist them in patient physical and non-physical care, since he considers the connection between the mind, body and spirit.

Thus, this study sought to seek answers to the following guiding question: How do nurses perform in the care provided to patients in palliative care, with emphasis on the spiritual dimension, in the light of Theory of Human Caring?

\section{OBJECTIVES}

To analyze nurses' role in assisting patients in palliative care, with emphasis on the spiritual dimension, in the light of Theory of Human Caring.

\section{METHODS}

\section{Ethical aspects}

The research was initiated after approval by an Institutional Review Board and met the recommendations contained in Resolution $466 / 2012^{(10)}$, which provides for research with human beings, including the guarantee of anonymity of participants and their consent to participate in the study, by signing the Informed Consent Form (ICF).

\section{Theoretical framework}

For the theoretical framework, we chose to use Theory of Human Caring, developed by Jean Watson ${ }^{(8)}$, and the 10 Caritas Process elements, described below: practicing loving-kindness, compassion and equanimity with oneself and with each other; being authentically present, enabling, sustaining and honoring faith and hope; cultivate one's own spiritual practices, beyond the ego to the transpersonal presence; developing and maintaining relationships of love, trust and affection; allowing the expression of positive and negative feelings, authentically listening to the other's story; using creativity to solve problems, seeking the solution through the care process; engaging in a genuine transpersonal teaching and learning experience; creating a healing environment at all levels (physical and non-physical); sustaining human dignity and respecting assistance for basic human needs; allowing miracles and open the spiritual, mysteries and the unknown ${ }^{(8,11-12)}$.

\section{Type of study}

This is a qualitative exploratory research, excerpted from the main author's thesis, which followed the criteria present in the Consolidated criteria for reporting qualitative research (COREQ) checklist, in order to improve the quality of qualitative research and assist in the performance of this research ${ }^{(13)}$.

\section{Methodological procedures}

Initially, the first contact with nurses was made. On that occasion, the main researcher presented the research proposal, addressing the theme, the objectives and the way in which data collection would be carried out. The interviews were carried out on a day and time scheduled with each participant, always seeking to ensure privacy and a calm and reserved environment, in addition to clarifying any doubts of participants regarding the research process.

\section{Study setting}

The study was conducted at a large public hospital in the city of João Pessoa, Paraíba, chosen for treating patients with a variety of life-threatening diseases, for having a qualified team to assist these patients and for involving the palliative care theme in professional training processes.

This hospital has a multidisciplinary team composed of doctors, nurses, nutritionists, psychologists, social workers, dentists, nursing technicians and occupational therapists. The hospital has an outpatient sector, medical, surgical, obstetric, pediatric and infectious diseases, surgical block, Intensive Care Unit, among others.

\section{Data source}

The population involved nurses from that institution and the sample consisted of 10 nurses working in the selected hospital during the data collection period, with at least six months of experience in the institution selected for the study. Professionals removed from their activities, due to vacation or leave, and those who did not work with a patient in palliative care, were 
excluded. Among the participating nurses, 9 were female and 1 male, aged between 33 and 60 years.

It should be noted that the sample quantum was given for convenience and was completed in view of the saturation of the interviews. Saturation identification is a relevant criterion for interrupting data collection and, consequently, for determining the final sample size in qualitative research ${ }^{(14)}$. In saturation, the completion of data collection occurs when the empirical material begins to show redundancy and repetition from the point of view of the interviewer ${ }^{(15)}$.

\section{Data collection and organization}

Data collection took place between August and December 2019 through semi-structured interviews and included questions about the nursing care provided to patients in palliative care; strategies to meet the dimensions of patients who are in palliative care; the relationship between nurses and patients in palliative care; meeting of spiritual needs of patients in palliative care; encouragement of religious and spiritual practices.

The interviews were recorded and transcribed in full. To maintain the anonymity of the participants, they were identified using the letter $\mathrm{N}$ (nurse), followed by the ordinal number, according to the sequence of the interviews (e.g., N1, N2, N3 and so on).

\section{Data analysis}

The analysis of the empirical material from the interviews was carried out through content analysis, proposed by Laurence Bardin. For this, the stages of pre-analysis, exploration of the material, treatment and interpretation of results were carried out ${ }^{(16)}$, which allowed the formation of the categories: The spiritual dimension of care is contemplated through religious and spiritual practices; The spiritual dimension of care is carried out with respect and encouragement to patients' religious and spiritual beliefs and practices; The spiritual dimension of care is carried out with personal, structural and professional training difficulties.

\section{RESULTS}

\section{Category I-The spiritual dimension of care is contemplated through religious and spiritual practices}

In this category, religious and spiritual practices performed by nurses stood out. These professionals considered prayer, reading the Bible, listening, talking, comforting words, presence, being together and providing for the arrival of a religious leader as expressions of the spiritual dimension of nursing care, with patients in palliative care.

[...]. Would you like to bring someone? [...] or someone from the church? Anything you would like to do? That we see that this brings relief to both the family and the patient [...]. (N2)

I listen, I observe what his religion is [...]. How far does his faith go, right? And then, many times, reaching out to say a prayer, take the hand. [...] pray a third with him [...]. It is more the presence, really, about being there next door, you know? [...]. (N5)
I think we try to pass a word of support, a word of comfort, talking about God every moment, and respecting [...]. It is to be present and pass on that you care about his pain and try to support him in whatever he needs [...]. (N7)

Sometimes, in a conversation, the patient expresses some desire and we try to answer: "I really wanted to go back to church, I wanted to be able to go one day!" And, like this, we keep trying, right? [...] if the patient is also not a Catholic, we talk, we pray with him and we ask him to come, if he needs it, some spiritual, religious leader [...]. We try to listen to the patient, his religion and if he wants us to ask the priest, we can call the pastor. (N8)

[...] yes, I can give this support without going into religious aspects, without going into dogma aspects, [...] giving spiritual support according to what the professional can offer, always asking if that patient wants to receive [..] if he wants a prayer, yeah, if he wants me to read a verse, if he wants a word, advice [...]. (N9)

[...] there have been patients who were evangelical. And then, for me, it's easier. Catholics are also easier. But I invite a spiritual mentor, I never did that. We pray, when they allow us to pray. [...] look, today there is a day of worship, today there is a day for Mass, do you want to go? [...]. (N10)

N5 and N9 highlight the importance of contemplating the spiritual dimension during care, for the relief of symptoms that the patient in palliative care may present, considering that, in life-threatening situations, it is possible that only medication does not promote the relief of the manifestations felt by patients.

[...] several times [...] he is complaining that the pain isn't going away, and you come close, take that hand, raise the thought of the Lord and say, "come on, come on, let's pray! Let's ask God"! And when we think, he reports, "I'm better. I'm much more relieved!" [...]. (N5)

[...]. We know that there will be no medication that will revert, there will be no analgesia that will work, but there will be a support word that will comfort [...] and it will be that word that will, many times, make a painkiller it stops being done, because he will be comfortable there with himself, and with a greater strength that he has [...]. (N9)

It is noteworthy that $\mathrm{N} 1$ and $\mathrm{N} 7$ report the need to prepare to be able to offer spiritual support to patients:

I believe that, for me to give spiritual support to a person, I also have to be prepared; if I am not prepared with myself, I will not be able to help others [...]. I am a person that whenever I can, I'm in prayer, right? so I can also strengthen myself and help that other person, who is often a little down. [...]. (N1)

So, I try to read the bible more, I try to pass it on to him, I try to strengthen myself, to give him the best. (N7)

\section{Category II - The spiritual dimension of care is carried out with respect and encouragement to patients' religious and spiritual beliefs and practices}

The statements presented by nurses in this category show the way the professional should behave when it comes to patients 
spiritual beliefs. Respect and encouragement of beliefs aim to meet patients' needs, to the point of improving their emotional condition and their responses to drug therapy.

[...] it's something that we have to have a lot of respect for, right? We can't impose, right? We know that this [spiritual practice] is good, right? So, if we hear from them, "look, I have faith in God that I will be fine! That it will appear the cure! When we see this path, we don't take away that joy [...]. I mean, we encourage, we motivate [...]. I believe that faith, really, as people say, "moves mountains", right? (N1)

I usually try to find out if he has any religious practice or if he has something he used to do that gave him that peace, regardless of belief in God or not. [...]. (N2)

We have patients from different faiths and they respect ours and we respect theirs. [...]. We have a mother of a saint, we have a Jew, an Islamist [...]. When the person says, I say, "Is it? How interesting, tell me more" [...]. And one thing I notice a lot is that the patient who has a lot of faith, who has faith in everything, even in a glass of water, he lives better, he is lighter, he gets lighter, his answers, including his medications they are better, and then, I praise [...]. (N4)

If he is an atheist, [...] we have to respect, right? So, we have to look for another way to intervene and help this person [...]. (N5)

Even though most nurses have stated that they encourage the religious and spiritual beliefs and practices of patients in palliative care, N8 says that they have not encouraged patients as a result of their work routine and, consequently, lack of time.

[...]. I think that by running, running from us, they are not encouraged, [...] but encouraging I think, I, on my part, no, I do not remember having encouraged, but trying to meet the patient's desire. [...]. (N8)

\section{Category III - The spiritual dimension of care is carried out with personal, structural and professional training difficulties}

In category III, most nurses express numerous difficulties in offering spiritual care to patients in palliative care, which are related to personal issues, professional training and the service structure. They mentioned as personal difficulties the fear that a patient will die on duty, as shown below:

[...]. So, we wonder why, as a professional, we pray so much that this patient does not go on his day. It's because we're not really prepared [...]. (N2)

N6 considers the spiritual dimension as something delicate, difficult, complicated; therefore, he limits himself to doing what he knows how to do, which is physical care and listening:

The spiritual dimension, this is more delicate, because, as I do not follow any religion, for me, it is more difficult to talk about it [...]. This is complicated. I don't see things very much on the spiritual side, understand? What I can do, what I can offer is what I said, I try to provide physical comfort... if there is any demand for something he wants to talk about, I will always be listening [...]. (N6)
N6 and N9, on the other hand, clarify that, because they do not have the ability to deal with spiritual matters, they turn to other professionals and that the performance of nursing is limited, little worked.

When a patient arrives who needs spiritual attention, I call colleagues who know how to work better in this sense. (N6)

[...] the patient is neglected as to these spiritual structures. [...]. I will not go into spiritual issues that l am unaware of, but I can also contact other professionals who have these skills. (N9)

Regarding the service structure, the routine of the service stands out with the high demand from patients and the lack of a specialized clinic to assist patients in palliative care. Participants recognize that patients are neglected, with spiritual assistance being the responsibility of each professional, i.e., nurses end up improving the development of this competence in practice.

[...] it is very difficult for nursing to be concerned with the spiritual part, because we already have a lot of volume for, right? to worry about. [...]. The bath I think is an important moment, where we discover a lot about the patient, because after that we will not have more time. Then, what happens, is that we say, "I could have done more", but we cannot do much if we do not want to spend more than a little time, because normally our time is very short [...]. (N3)

$\mathrm{N} 4$ adds that he did not seek to identify patients' spiritual needs and argues that spirituality can be considered as a work strategy:

[...] I never thought about what the patient seeks with religiousness, spirituality. [...]. This is an issue for us to think about and maybe even use as a work strategy [...]. (N4)

As for training, N2 evidenced the lack of knowledge about spiritual issues and knowledge restricted to drug therapy.

[...] we have difficulty and a lack of knowledge. We already had patients that geriatrics needed to make an intervention and come to talk to us even to train [...] we are also unprepared to accompany death, [...] to speak frankly about finitude [...], we don't know much about what other alternatives, what other therapies to use other than just the medications [...]. (N2)

N6 and N7 reported the need for professional training to deal with the spiritual dimension of nursing care provided to patients in palliative care. They also reported the lack of a specialized palliative care clinic.

[...] I don't really have, like, any acting. Yeah, I never had training, training in palliative care [...]. (N6)

Often, we have a very large number of patients and do not have a clinic in the hospital, it is appropriate for that [...]. I think that if we had a separate specialized clinic, right?! [...] I think that the professionals would be a little more qualified, and would seek a better understanding to be able to try to pass on to the patient this way of seeing the passage, to see death as something natural, something that is expected, right?! (N7) 


\section{DISCUSSION}

Considering the suffering of patients with serious and fatal illness and the suffering of their family, it is necessary to develop human care based on scientific evidence, to enable more effective responses to the problems faced by the disease. Theory of Human Caring can be an approach used in these cases, as it is equivalent to what palliative care proposes, including attention to spiritual aspects ${ }^{(17)}$.

Among the religious and spiritual practices carried out by the nurses in this research, prayer, Bible reading, listening, conversation, words of comfort, presence and providence of a religious leader stood out. These practices, characterize the spiritual care they perform, since they are understood by them as a support, a strength, a comfort to meet the health needs of patients in palliative care, at the moment, and may even avoid the use of medication.

A qualitative study, based on Theory of Human Caring, carried out at a geriatric center in Salvador, with 17 nurses, showed that they also perform and encourage prayer, the reading of biblical words and respond to requests from religious representatives to assist the spiritual dimension of hospitalized elderly people ${ }^{(18)}$.

These actions denote nurses' idea being authentically present, allowing the belief system and the subjective world of themselves and the other, so that it affirms faith and hope, as well as develops and maintains a relationship of help, trust, love and affection present, respectively, to the second and fourth Caritas Process elements ${ }^{(8,12)}$.

Nursing care should open up the spiritual aspects, mysteries of life, death, pain, joy and changes, allowing for miracles, as evidenced in the tenth element Caritas Process element ${ }^{(8,12)}$. Emphasis is placed on the relevance of the role that faith and hope play in people's lives, especially when faced with the unknown, mysteries and diseases, pain, stress, despair, sadness, fear, and death ${ }^{(19)}$.

In the face of a life-threatening situation, with medication no longer having the desired effect, spiritual care emerges as a therapeutic option, providing basic needs as sacred acts, sustaining human dignity and creating a healing environment in all aspects, physical and non-physical, both present in the ninth and eighth Caritas Process elements, respectively ${ }^{(8,11-12)}$.

Nurses' acknowledgment of a threatening environment for patients, the development of an empathic relationship, a modifying attitude, allied with the use of technical procedures, all this forms the basis for restoring health and meeting basic human needs. Considering the human complexity and its biopsychoemotional and spiritual dimensions, it is necessary to reflect on the implementation of nursing care that contemplates not only the physical, but the other dimensions of the human being ${ }^{(20)}$. To promote the well-being of individuals, it is necessary to have an environment that allows healing through care, providing comfort, peace and harmony ${ }^{(21)}$.

Listening and talking with patients, performed by nurses, must be authentic and allow the expression of feelings, whether positive or negative, as proposed by Watson, in his fifth element ${ }^{(8,12)}$. Many problems can arise in nursing, such as failure to build an empathic relationship with the other. However, it is necessary to understand that nurses, when engaging with patients, at the moment of care, and really listening to their story, may be offering the greatest healing gift and may allow patients to feel more comfortable talking about issues delicate things that are really affecting them ${ }^{(19)}$.

It was found that encouragement and respect for spiritual and religious beliefs and practices were referred to as adopting an attitude of not imposing professionals' opinion, but of motivating, encouraging dialogue, praising, identifying a spiritual need, looking for an alternative, another way of intervene and help. These statements represent the third Caritas Process element. This element concerns the cultivation of spiritual beliefs and practices ${ }^{(8,12)}$.

This can facilitate the construction of a trustworthy relationship, which helps care. In order to develop sensitivity, oneself need to pay attention to their own feelings and thoughts. By adopting a spiritual practice to connect with the inner self, individuals extrapolate the physical dimension and seeks a deeper source of inner wisdom and the truths themselves. The practice of selfreflection, through registration, prayer, meditation and artistic expression, demonstrates the willingness to explore the feelings, beliefs and values of others for personal growth ${ }^{(19)}$.

Furthermore, it was possible to perceive the cultivation of practices of loving kindness, compassion and equanimity with oneself and with others, the first Caritas Process element ${ }^{(8,12)}$, considering that this element can be represented by help acceptance and offer and for being authentically present ${ }^{(21)}$.

It was evidenced that the majority of nurses participating in this research encourage, respect and perform spiritual care for patients in palliative care. Respect for patients' religious practice was strongly emphasized in nurses' statements. The varied beliefs, and the willingness of nurses to attend to patients' spiritual dimension, show respect for the other, an understanding of the other's subjective world and the relevance of this dimension ${ }^{(18)}$.

Teaching and learning relationships within the context of care, the seventh element of the process ${ }^{(8,12)}$ were highlighted by N4, when he reported that he likes to learn about patients' religions. It is known that in nursing, patient education is very present. However, little is mentioned about the learning that one has with patients and that is encouraged by Theory of Human Caring.

The Caritas teaching and learning process does not allow the authoritarian approach of nurses due to their professional position. On the contrary, it is a relational, confident, engaging and liberating process, resulting in possibilities of self-knowledge, self-care, self-control and even self-healing ${ }^{(19)}$.

Among the problems related to the lack of incentive to spiritual and religious practices and beliefs, there was a lack of time among nursing professionals, since, in view of other care attributions, they may not be able to provide assistance that contemplates body-mind-soul. A qualitative study, carried out with 27 nursing assistants, showed that this lack of time, associated with the exhaustive work routine, the lack of knowledge about the spiritual dimension, care centered on the biological dimension and the absence of emotional support to the team, all of this contributes to hinder the spiritual dimension in palliative care ${ }^{(22)}$.

Nurses also reported personal difficulties, professional training, and related to the structure of the service to meet the spiritual dimension of patients in palliative care. Among the personal 
difficulties, the lack of preparation to deal with death and the lack of skills to attend to the spiritual dimension stood out, including, for associating this only with religious issues.

Bearing in mind that spirituality is based on sacred values that transcend the physical world and the reality that can be seen, its understanding becomes difficult and, consequently, its incorporation in care directed to patients in palliative care is difficult ${ }^{(23)}$.

It should be noted that sacred acts and transcendence are present in Theory of Human Caring. The administration of sacred acts of care and healing in order to provide holistic care; also, attention to spiritual aspects is part of the ninth Caritas Process element $^{(11)}$, as mentioned. As nurses perform these functions, they bring the spirit to the physical dimension, which promotes new connections between basic and evolving spiritual needs. In this way, each act of the physical dimension connects with the spirit dimension and changes individuals' lives. Nurses help others, as a sacred act, and recognize that, with this act, they connect and contribute to the spirit of themselves and that of the other ${ }^{(19)}$.

Transcendence is part of the concept of transpersonal care, understood by Watson as intersubjectivity in the relationship between humans, in which there is the influence of those involved in the process. This transpersonal relationship denotes the idea of union with another person. It starts when nurses enter patients' phenomenological field, being able to identify in their hearts the spirit of patients ${ }^{(8)}$. Thus, performing transpersonal care is of great importance to know what is not possible to see in the assisted patient. However, this is not always easy to do.

This makes it possible to understand the importance of attending the spiritual dimension in patient care and carrying out the Caritas Process, especially in the face of a patient weakened by his health condition, although there are difficulties in performing this service in clinical practice.

Some nurses in this research stated that they were unable to meet the spiritual dimension of their patients in palliative care. They reported resorting to other professionals with competence to perform this type of care, also found in other studies ${ }^{(7,24)}$. The collaboration of several professionals is a great way to offer excellent service. This interprofessional human care must be attentive to the mysteries of life and spiritual ${ }^{(21)}$. Furthermore, professional training and a specialized care environment for patients with life-threatening diseases could facilitate meeting this need, as evidenced in the statements.

Nurses recognize the need for spiritual support of patients in palliative care as legitimate and attribute the unpreparedness to lack of knowledge, since in training they only knew about drug therapy and as a result, they are not prepared to deal with finitude. They claim the need for training to assist patients with life-threatening diseases. They understand that all of this leads to a loss in patient care. Even due to the high demand for work, this assistance is neglected.

In this context, Resolution 41 of the Ministry of Health of Brazil addresses the guidelines for the organization of palliative care services in the Unified Health System (SUS - Sistema Único de Saúde). Among its objectives are the provision of permanent education for health professionals, the encouragement of multidisciplinary work and the promotion of curricular components on palliative care in lato sensu (Master of the Arts) undergraduate and graduate teaching in Brazil $^{(4)}$, which will assist in assisting patients with life-threatening diseases and meeting their biopsychosocial and spiritual needs. The Caritas Process itself can be used as part of the programmatic content of training in palliative care in health services to promote patient care and care for spiritual aspects ${ }^{(17)}$.

Searching for alternatives that help patients in the care of their spiritual dimension is reflected in the sixth Caritas Process, which deals with the use of creative methods for problem solving and in decision-making about care ${ }^{(25)}$; including, nurses' reports about the moments when they were able to provide spiritual assistance highlight this element of care. In human care for patients, professionals need to use their creativity, which requires all forms of combined knowledge (science, art, ethics and personal experiences) so that the manifestation of the science of care is enhanced $^{(21)}$.

Considering the above, it is emphasized that the spiritual dimension needs to be ensured in the assistance of nurses to patients, for their holistic care. Assistance directed to the spiritual dimension, in addition to considering humanistic aspects in care, allows the improvement of well-being and quality of life of patients ${ }^{(18)}$, being congruent with what advocates palliative care.

\section{Study limitations}

Among the study limitations, it is worth mentioning that it was carried out at only one hospital that assists patients in palliative care. Another limitation concerns the non-use of the systematic observation technique, which could help to verify the application of the Caritas Process elements during nurses' care practice and contribute to strengthening the findings found in this research.

\section{Contributions to nursing, health, and public policy}

This research has important contributions in nursing and health, considering that it may encourage the production of studies on Jean Watson's Theory of Human Caring and, consequently, the application of the Caritas Process in the care of the spiritual dimension of patients who have a life-threatening disease, whose spiritual aspects need to be attended to and may have greater relevance than physical care considering the finitude of life and the impossibility of a cure.

The dissemination of this study may alert nurses about the knowledge of nursing theories, with emphasis on Jean Watson's Theory and its important application in the practice of patientoriented care. In this case, patients in palliative care. It is also noteworthy that nurses will be able, from this study, to realize that they empirically use the theory in question, thus, it will also be able to encourage them to seek more scientific basis for their practice.

\section{FINAL CONSIDERATIONS}

In this study, it was possible to verify that most nurses understand spirituality as an important resource for caring for patients in palliative care; they even respect and offer religious and spiritual practices during their care, despite finding difficulties in their application, with emphasis on unpreparedness and lack of time.

It is also evident that nurses have attitudes consistent with Jean Watson's Theory of Human Caring and apply the Caritas 
Process elements, even empirically. However, it is understood that a qualification aimed at professionals who care for patients in palliative care, focused on this theory and the care of the spiritual dimension, can offer higher quality care, seeking to care for patients as a sacred being that must be fully respected.

It is suggested that further studies be carried out to assess the care of the nursing team, through systematic observation, in order to verify the Caritas Process elements present in nurses actions. Moreover, studies are needed that contemplate the conduct of nursing professionals, before and after conducting training that addresses Theory of Human Caring and the Caritas Process elements, applied to the hospital context. Such studies may enable the growth of these professionals, contributing to significant changes in their clinical practice.

\section{REFERENCES}

1. Silva MHF. Cuidados paliativos e envelhecimento: abordagem de serviços no sistema único de saúde (SUS). Rev Med Minas Gerais. 2019:e2039. https://doi.org/10.5935/2238-3182.20190056

2. Franco HCP, Stigar R, Souza SJP, Burci LM. Papel da enfermagem na equipe de cuidados paliativos: a humanização no processo da morte e morrer. Rev Gestão Saúde [Internet]. 2017 [cited 2020 Jun 2];17(2):48-61. Available from: http://www.herrero.com.br/files/revista/ file56fb2faad065b8f7980ccdf2d0aa2da1.pdf

3. Radbruch L, Lima LL, Knaul F, Woodruff R, Yong J, Pastrana T, et al. Redefining palliative care: a new consensus-based definition. J Pain Symptom Manag. 2020;60(4):754-64. https://doi.org/10.1016/j.jpainsymman.2020.04.027

4. Ministério da Saúde (BR). Resolução n 41, de 31 de outubro de 2018. Dispõe sobre as diretrizes para a organização dos cuidados paliativos, à luz dos cuidados continuados integrados, no âmbito Sistema Único de Saúde (SUS) [Internet]. Diário Oficial da União 2018 [cited 2020 Jun 2]. Available from: https://portalarquivos2.saude.gov.br/images/pdf/2018/novembro/23/RESOLUCAO-N41.pdf

5. Gomes ALZ, Othero MB. Cuidados paliativos. Estud Av. 2016;30(88):155-66. https://doi.org/10.1590/s0103-40142016.30880011

6. Picollo DP, Fachini M. A atenção do enfermeiro ao paciente em cuidado paliativo. Rev Ciênc Méd. 2018;27(2):85-92. https://doi. org/10.24220/2318-0897v27n2a3855

7. Evangelista CB, Lopes MEL, Costa SFG, Abrão FMS, Batista PSS, Oliveira RC. Spirituality in patient care under palliative care: a study with nurses. Esc Anna Nery. 2016;20(1):176-82. https://doi.org/10.5935/1414-8145.20160023

8. Watson J. Human caring science: a theory of nursing. 2. ed. Sudbury: Jones \& Bartlett Learning; 2012.

9. Evangelista CB, Lopes MEL, Costa SFG, Batista PSS, Batista JBV, Oliveira AMM, et al. Palliative care and spirituality: an integrative literature review. Rev Bras Enferm. 2016;69(3):591-601. https://doi.org/10.1590/0034-7167.2016690324i

10. Ministério da Saúde (BR). Resolução n 466/12, de 12 de dezembro de 2012 [Internet]. 2012 [cited 2020 Aug 30]. Available from: http:// bvsms.saude.gov.br/bvs/saudelegis/cns/2013/res0466_12_12_2012.html

11. Nelson J, DiNapoli P, Turkel M, Watson J. Concepts of caring as constructo of caritas hierarchy in nursing knowlwdge: conceptual-theoreticalempirical (CTE). In: Nelson J, Watson J. Measuring Caring: International Research on Caritas as Healing. New York: Springer Publishing Company; 2011.

12. Watson J. Unitary Caring Science: the philosophy and práxis of nursing. Luisville: University Press of Colorado; 2018.

13. Tong A, Sainsbury P, Craig J. Consolidated criteria for reporting qualitative research (COREQ): a 32-item checklist for interviews and focus groups. Int J Qual Health Care. 2007;19(6):349-57. https://doi.org/10.1093/intqhc/mzm042

14. Nascimento LCN, Souza TV, Oliveira ICS, Moraes RMM, Aguiar RCB, Silva LF. Theoretical saturation in qualitative research: an experience report in interview with schoolchildren. Rev Bras Enferm. 2018;71(1):243-8. https://doi.org/10.1590/0034-7167-2016-0616

15. Ribeiro J, Souza FN, Lobão C. Saturação da análise na investigação qualitativa: quando parar de recolher dados? Rev Pesqui Qual [Internet]. 2018 [cited 2020 Jul 10];6(10):3-7. Available from: https://editora.sepq.org.br/rpq/article/view/213/111

16. Bardin L. Análise de Conteúdo. Lisboa: Edições 70; 2016.

17. Aghaei MH, Vanaki Z, Mohammadi E. Watson's Human Caring Theory-Based Palliative Care: a discussion paper. Int J Cancer Manag. 2020;13(6):e103027. 2020. https://doi.org/10.5812/ijcm.103027

18. Veras SMCB, Menezes TMO, Guerrero-Castañeda RF, Soares MV, Anton Neto FR, Pereira GS. Nurse care for the hospitalized elderly's spiritual dimension. Rev Bras Enferm. 2019;72(suppl 2):236-42. https://doi.org/10.1590/0034-7167-2018-0685

19. Watson J. Nursing: the philosophy and science of caring. Colorado: University Press of Colorado; 2008.

20. Savieto RM, Leao ER. Nursing assistance and Jean Watson: a reflection on empathy. Esc Anna Nery. 2016;20(1):198-202. https://doi. org/10.5935/1414-8145.20160026

21. Wei $\mathrm{H}$, Watson J. Healthcare interprofessional team members' perspectives on human caring: a directed content analysis study. Int J Nurs Sci. 2019;6(1):17-23. https://doi.org/10.1016/j.ijnss.2018.12.001

22. Matos JC, Guimarães SMF. The application of transpersonal and spiritual care for older adults receiving palliative care. Rev Bras Geriatr Gerontol. 2019;22(5):e190186. https://doi.org/10.1590/1981-22562019022.190186 
23. van der Weegen $\mathrm{K}$, Hoonder M, Timmermann M, van der Heide A. Ritualization as alternative approach to the spiritual dimension of palliative care: a concept analysis. J Relig Health. 2019;58(6):2036-46. https://doi.org/10.1007/s10943-019-00792-z

24. Burkhart L, Bretschneider A, Gerc S, Desmond ME. Spiritual care in nursing practice in veteran health care. Global Qual Nurs Res. 2019;6:1-9. https://doi.org/10.1177/2333393619843110

25. Sitzman K, Watson J. Caring Science, mindful pratice: implementing Watson's Human Caring Theory. New York: Springer Publishing Company; 2013. 